\title{
Pengembangan dan Uji coba Media Pembelajaran Praktikum Laboratorium Manajemen Rekam Medis Berbasis Video Tutorial
}

\author{
Puput Sugiarto, Hidayatul Maula, Dian Wara Dewi, Nadzia Farahdin Agnur \\ Poltekkes Kemenkes Semarang, Semarang, Indonesia \\ Jl. Tirto Agung, Pedalangan, Banyumanik, Semarang \\ Korespondensi E-mail: puputsugiartormik@gmail.com
}

Submitted: 5 Februari 2021, Revised: 23 Juni 2021, Accepted: 27 Juni 2021

\begin{abstract}
The Implementation of learning on Prodi D3 RMIK Poltekkes Kemenkes Semarang includes learning in the classroom, laboratory, and field with learning methods that have been developed. Practical learning both in laboratory and field are important things that must be considered in vocational education. Therefore, it is necessary to emphasize practical learning both laboratory and field. It's also necessary to develop the laboratory practicum learning tool related to medical record management on Prodi D3 RMIK. The research method that we used is research and development method (R\&D). This research step includes analysis of needs, design, validation design, and trial of the design result. This research aims to produce certain products and test the effectiveness of these products. In this research, we made a video tutorial for medical record management practicum. The results of the 3 video research have been validated by experts with conclusions, all the three of them are "valid" and "very valid" in material testing and media testing. From the practicality test toward the videos, we got "practical" and "very practical" as the result. Meanwhile from the effectiveness test toward the videos, we got "effective" as the result.
\end{abstract}

Keywords: tutorial video, practicum, medical record management

\begin{abstract}
Abstrak
Pelaksanaan pembelajaran pada Prodi D3 RMIK Poltekkes Kemenkes Semarang meliputi pembelajaran teori klasikal, praktik laboratorium, dan lapangan dengan metode pembelajaran yang telah dikembangkan. Pembelajaran praktik di laboratorium dan lapangan merupakan hal penting yang harus diperhatikan dalam pendidikan vokasional. Oleh karena itu, perlu adanya penekanan pembelajaran praktik baik laboratorium maupun lapangan. Diperlukan pula pengembangan media pembelajaran praktikum laboratorium terkait manajemen rekam medis pada Prodi D3 RMIK. Metode penelitian ini menerapkan metode penelitian dan pengembangan (research and development/R\&D). Tahapan pada penelitian ini meliputi analisis kebutuhan, perancangan desain, validasi rancangan, dan uji coba hasil perancangan. Tujuan dari penelitian ini adalah menghasilkan suatu produk baru atau hasil modifikasi serta menguji keefektifan dari produk yang dihasilkan. Produk yang dihasilkan dalam penelitian ini berupa video tutorial praktikum manajemen rekam medis. Hasil penelitian 3 video telah mendapatkan validasi oleh ahli atau pakar dengan kesimpulan valid dan sangat valid dalam uji materi dan uji media. Uji praktikalitas terhadap video diperoleh hasil praktis dan sangat praktis. Uji keefektivitasan terhadap video diperoleh hasil efektif.
\end{abstract}

Kata Kunci : video tutorial, praktikum, manajemen rekam medis

\section{Pendahuluan}

Proses pelaksanaan pembelajaran pada Prodi D3 RMIK menerapkan kurikulum yang mengadopsi dari BPPSDMKes dan APTIRMIKI. Berdasarkan bobot SKS yang ada, muatan praktik dan lapangan telah mencapai 55\% dimana untuk pendidikan vokasional dititikberatkan pada pelaksanaan praktik.(1) Pembelajaran pada Prodi D3 RMIK Poltekkes Kemenkes Semarang adalah pembelajaran teori klasikal, praktik laboratorium, dan lapangan dengan metode pembelajaran yang telah dikembangkan. Pembelajaran praktik di laboratorium dan lapangan merupakan hal penting yang harus diperhatikan dalam pendidikan vokasional. Pendidikan vokasional lebih menitikberatkan pada keterampilan mahasiswa dalam penyelesaian masalah (problem solving). Maka dari itu, diperlukan adanya penekanan pembelajaran praktik baik laboratorium maupun lapangan. 
Dalam tahapan proses pembelajaran, hendaknya diperlukan pengembangan strategi yang dimulai dari tahap perencanaan hingga pelaksanaan. Pada tahap perencanaan, dosen melakukan perumusan tujuan pembelajaran secara jelas yang harus dicapai. Tahap pelaksanaan, terjadi interaksi antara mahasiswa dengan dosen untuk mencapai tujuan belajar. Dengan mempertimbangkan situasi lingkungan dan karakteristik mahasiswa, kegiatan pembelajaran harus berpusat kepada mahasiswa, belajar aktif, mengembangkan kemampuan sosial, keingintahuan, imajinasi, keterampilan pemecahan masalah, kreatif, penggunaan IPTEK, menumbuhkan kesadaran sebagai warga negara yang baik dan keinginan belajar sepanjang hayat.(2)

Berdasarkan penelitian yang dilakukan oleh peneliti sebelumnya, telah diperoleh informasi bahwa gaya belajar mahasiswa D3 RMIK adalah 29,8\% kinestetik, 27,6\% auditori-visual-kinestetik dan $21,3 \%$ visual. Dari hasil penelitian tersebut telah dikembangkan strategi pembelajaran berbasis gaya belajar dimana lebih mengedepankan parktik secara langsung (direct) dan strategi pembelajaran melalui pengalaman (eksperimental). Strategi pembelajaran tersebut telah efektif dalam meningkatkan nilai mahasiswa.(3) Oleh karena itu, diperlukan pengembangan lagi dalam pembelajaran praktikum salah satunya melalui inovasi media pembelajaran.

Berdasarkan penelitian Andreas yang mengembangkan media pembelajaran berbasis video tutorial terkait mata kuliah mekanika tanah dan teknik pondasi diperoleh hasil bahwa video tutorial yang dihasilkan dapat meningkatkan nilai mahasiswa.(4) Melalui hasil penelitian tersebut diperlukan pula pengembangan media pembelajaran praktikum laboratorium terkait manajemen rekam medis pada Prodi D3 RMIK. Saat ini pembelajaran praktikum dilakukan melalui penjelasan secara lisan terkait dengan SOP praktikum dan dalam bentuk power point sehingga perlu dikembangkan lebih lanjut melalui media video tutorial. Melalui video tutorial ini diharapkan mahasiswa dapat melihat dan mendengarkan secara langsung alur dan prosedur pelaksanaan praktikum sehingga akan mempermudah pemahaman mahasiswa sebelum dimulainya kegiatan praktikum secara langsung oleh mahasiswa melalui role play.

Video tutorial yang dibuat adalah video tutorial praktikum pada mata kuliah manajemen rekam medis. Mata kuliah tersebut ditempuh oleh mahasiswa pada semester genap (dua). Dalam kegiatan praktikum meliputi tata cara pendaftaran pasien, koding, dan filing. Video tutorial yang telah dibuat kemudian disosialisasikan kepada mahasiswa dan diukur tingkat keefektifan dalam penggunaan video tutorial tersebut.

\section{Metode Penelitian}

Metode penelitian yang digunakan adalah metode penelitian dan pengembangan (research and development). Penelitian ini bertujuan untuk menghasilkan produk video tutorial pembelajaran praktikum laboratorium dan menguji keefektifan produk tersebut.(5) Dalam penelitian ini dilakukan pembuatan video tutorial pembelajaran praktikum laboratorium manajemen rekam medis.

Lokasi penelitian dilaksanakan di Laboratorium Rekam Medis dan Informasi Kesehatan Jurusan Rekam Medis dan Informasi Kesehatan Poltekkes Kemenkes Semarang. Waktu penelitian dilaksanakan pada bulan Juni sampai November 2020. Subjek penelitian adalah mahasiswa Jurusan RMIK Poltekkes Kemenkes Semarang khususnya mahasiswa semester I Prodi D3 RMIK. Objek penelitian adalah video tutorial pembelajaran praktikum laboratorium manajemen rekam medis yang meliputi tata cara pendaftaran pasien, koding, dan filing.

Jenis data yang dikumpulkan dalam penelitian ini meliputi data primer dan data sekunder. Pengumpulan data primer untuk menemukan kebutuhan mahasiswa dalam pembelajaran praktikum laboratorium melalui Forum Group Discussion (FGD). Selain itu, data primer diperoleh melalui studi dokumentasi terhadap kajian video tutorial serta SOP kegiatan-kegiatan dalam manajemen rekam medis. Pengumpulan data sekunder dilakukan dengan studi dokumentasi terhadap SOP Pelayanan Rekam Medis yang akan dipraktikkan di laboratorium.

Alat yang digunakan untuk pengumpulan data menggunakan angket atau kuesioner. Data angket yang digunakan dalam bentuk ceklist dengan skala likert. Angket yang sudah dipersiapkan kemudian diberikan kepada ahli untuk mengetahui kevalidan dari media pembelajaran berupa video tutorial praktikum. Teknik pengumpulan data dengan menggunakan angket juga digunakan pada subjek penelitian terhadap produk yang dirancang. Angket yang dibagikan kepada subjek penelitian untuk 
mengetahui tingkat praktikalitas dalam penggunaan video pembelajaran. Selain itu, subjek penelitian akan diberikan pretest dan posttest untuk mengetahui tingkat efektivitas video pembelajaran. Adapun aspek yang dinilai dalam angket uji materi dan uji media kepada ahli ditampilkan dalam Tabel 1 dan Tabel 2. Kriteria Interpretasi Skor Angket Validasi Ahli dan Skor Angket Praktikalitas pada Tabel 3 sebagai berikut(6):

Tabel 1.

Angket Uji Materi

\begin{tabular}{lll}
\hline No & Aspek Penilaian & \multicolumn{1}{c}{ Indikator } \\
& & \\
\hline 1 & Isi Materi & Kesesuaian dengan RPS \\
& Relevansi dengan kemampuan mahasiswa \\
& Kejelasan topik pembelajaran \\
& Keurutan materi \\
& Cakupan materi \\
& Ketuntasan materi \\
& Kesesuaian desain \\
& Relevansi gambar, video, ilustrasi dengan materi \\
& & Kemudahan penggunaan media \\
& & Kemudahan memahami materi \\
& Strategi Pembelajaran & Sumber: Ritonga, AM, 2020
\end{tabular}

Sumber: Ritonga, AM, 2020

Tabel 2.

Angket Uji Media

\begin{tabular}{lll}
\hline No & Aspek Penilaian & \\
& & \\
\hline 1 & Komunikasi & Kemudahan memulai video \\
& Logika berpikir \\
& Interaksi dengan pengguna \\
& Kejelasan petunjuk penggunaan \\
& Penggunaan Bahasa \\
& Format teks \\
& & Penggunaan warna \\
& & Kualitas gambar \\
& & Kualitas video \\
& & Penggunaan animasi \\
& & Kejelasan suara \\
& Urutan penyajian \\
& Penggunaan backsound \\
& Transisi antar isi materi \\
& Tampilan program \\
\hline & Sumber: Ritonga, AM, 2020
\end{tabular}

Teknik analisis data praktikalitas menggunakan perhitungan:

$$
\text { Presentase }=\frac{\text { Total Skor }}{\text { Skor Maksimum }} \times 100 \%
$$


Tabel 3.

Kriteria Interpretasi Skor Angket Validasi Ahli dan Skor Angket Praktikalitas

\begin{tabular}{ccc}
\hline Nilai Validitas & Tingkat Kriteria Validasi & Tingkat Kriteria Kepraktisan \\
\hline $81 \%-100 \%$ & Sangat Valid & Sangat Praktis \\
$61 \%-80 \%$ & Valid & Praktis \\
$41 \%-60 \%$ & Cukup Valid & Cukup Praktis \\
$21 \%-40 \%$ & Tidak Valid & Tidak Praktis \\
$0 \%-20 \%$ & Sangat Tidak Valid & Sangat Tidak Praktis \\
\hline
\end{tabular}

Sumber: (Modifikasi Sugiyono, 2016)

\section{Hasil dan Pembahasan Analisa Kebutuhan}

Untuk dapat mengetahui apa saja video yang akan dikembangkan dengan mempelajari bahan kajian dan Rencana Pembelajaran Semester (RPS) pada mata kuliah manajemen rekam medis. Pada mata kuliah Manajemen Rekam Medis dipelajari tata cara dan prosedur dalam pengelolaan rekam medis pasien yang meliputi pendaftaran pasien, assembling, analisis, koding, indeksing, filing, pelaporan dan pelepasan informasi.(7) Dikarenakan pada kompetensi assembling, analisis, indeksing, pelepasan informasi dan pelaporan akan dibahas lebih lanjut pada mata kuliah selanjutnya, maka pengembangan video tutorial praktikum ini ditekankan pada prosedur pendaftaran pasien, koding, dan filing.

Prosedur pendaftaran merupakan kegiatan yang memberikan pelayanan pendaftaran kepada pasien baik pasien baru maupun pasien lama pada pelayanan rawat jalan, rawat inap, maupun darurat. Prosedur koding merupakan suatu kegiatan memberikan pengklasifikasian dan pengodingan terhadap diagnosa dan tindakan medis baik pada pelayanan rawat jalan maupun rawat inap. Prosedur filing merupakan kegiatan penyimpanan rekam medis dan pengambilan kembali rekam medis untuk pendokumentasian pelayanan pasien.(8)

Langkah selanjutnya adalah mempelajari terkait studi dokumentasi tata cara pendaftaran, koding, dan filing berdasarkan pedoman tertulis yang berlaku pada Pedoman Penyelenggaraan Rekam Medis di Sarana Pelayanan Kesehatan yang telah dikeluarkan oleh Kementerian Kesehatan. Untuk memperkaya referensi(9), dilakukan pula Forum Group Discussion (FGD) kepada Clinical Instructure (CI) Rumah Sakit. CI Rumah Sakit yang dilibatkan dalam penelitian ini adalah CI dari RSUD Tugurejo Semarang, RSUD Kelet Jepara, dan RSJ Prof. Dr. Soerojo Magelang. FGD yang dilakukan membahas bagaimana prosedur baku dalam proses pendaftaran pasien, pengkodean diagnosis dan tindakan, serta prosedur penyimpanan dan pengambilan kembali rekam medis pasien.

Tahapan penelitian pengembangan ini, setelah identifikasi masalah, maka dilanjutkan dengan analisa kebutuhan dengan mengumpulkan data yang ada. Penelitian ini telah dilakukan pengumpulan data melalui FGD dengan CI rumah sakit dan melalui studi dokumentasi terkait dengan prosedur pelayanan pendaftaran pasien, kodefikasi diagnosis dan tindakan medis, serta penyimpanan dan pengambilan kembali rekam medis. Hal ini sesuai dengan apa yang disampaikan oleh Sugiyono yaitu setelah potensi dan masalah dapat ditunjukkan secara faktual dan up-to-date, maka selanjutnya perlu dikumpulkan berbagai informasi yang dapat digunakan sebagai bahan untuk perencanaan produk tertentu yang diharapkan dapat mengatasi masalah tersebut.(5)

\section{Pembuatan Video Tutorial}

Prosedur yang telah ditetapkan pada tahap analisa kebutuhan, dituangkan dalam materi paparan video yang dilengkapi dengan pengertian, tujuan, serta beberapa materi pendukung. Persiapan yang dilakukan untuk simulasi adalah menyiapkan skenario video. Skenario meliputi teks yang harus dibacakan oleh pengisi suara dan langkah-langkah kerja yang akan direkam. Selain itu, disiapkan pula alat, bahan, serta tempat yang akan digunakan untuk pengambilan video. Tempat yang digunakan adalah Laboratorium RMIK Jurusan RMIK Poltekkes Kemenkes Semarang. Langkah selanjutnya adalah dilakukan FGD antara peneliti dengan pihak ketiga yang membantu dalam pengambilan video serta editing 
video. FGD dilakukan untuk persamaan persepsi bagaimana konsep video yang akan dibuat, menentukan setting tempat dan waktu. Dalam FGD telah disepakati prosedur dalam pengambilan video. Pemeran dalam video diperankan langsung oleh anggota peneliti.

Hasil FGD diimplementasikan secara langsung dalam proses pembuatan video. Setelah pengambilan video, dilakukan langkah editing video oleh pihak ketiga. Hasil dari pembuatan video masingmasing berdurasi selama 4 - 5 menit dengan dihasilkan 3 video yang meliputi video pendaftaran pasien, video koding, dan video filing (Gambar 1a-c).

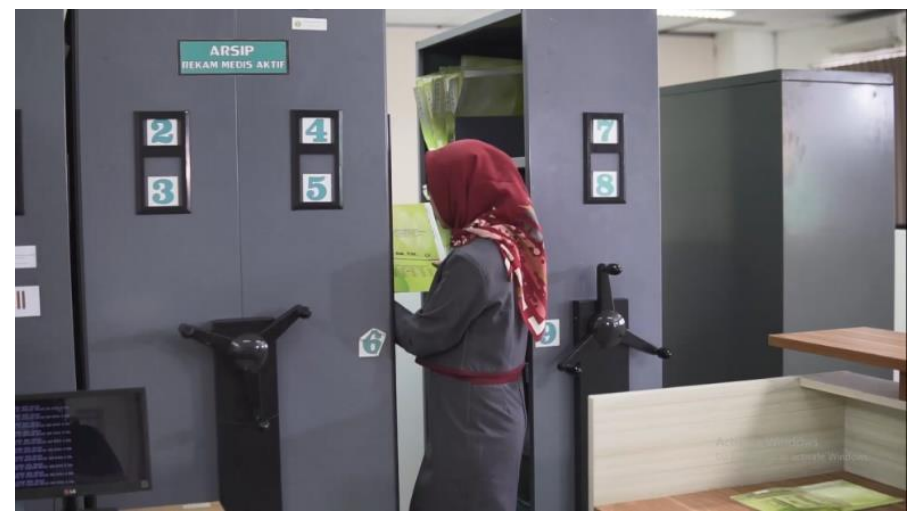

Gambar 1a.

Video Tutorial Praktik Filing Rekam Medis

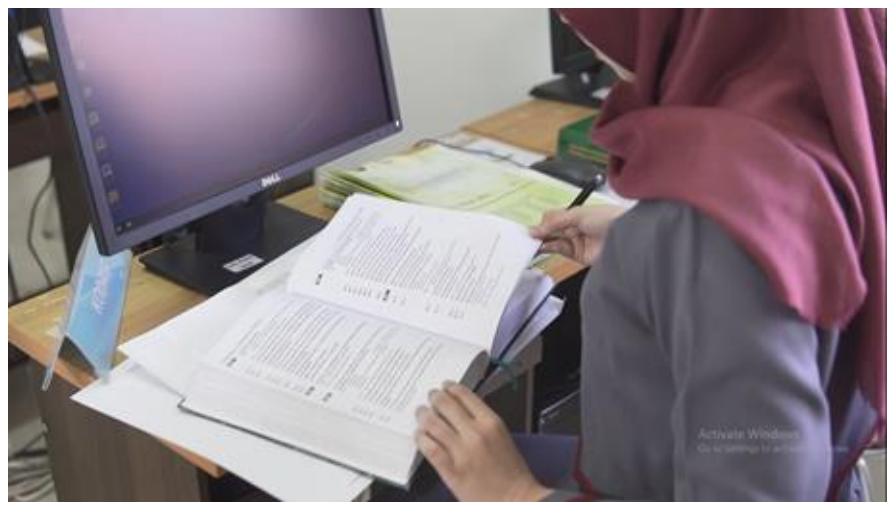

Gambar 1b.

Video Tutorial Praktik Koding Diagnosis dan Prosedur

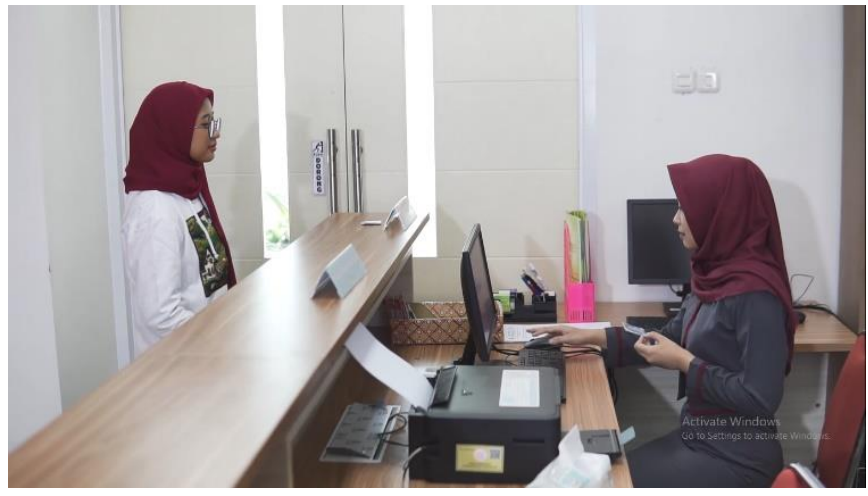

Gambar 1c.

Video Tutorial Praktik Pendaftaran Pasien Rawat Jalan 
Menurut Sugiyono, produk yang dihasilkan dalam penelitian R\&D bermacam-macam. Dalam teknologi, orientasi produk teknologi yang dapat dimanfaatkan untuk kehidupan manusia adalah produk yang berkualitas, hemat energi, menarik, harga murah, bobot ringan, ergonomis, dan bermanfaat ganda.(5) Begitu pula dengan produk video tutorial ini diharapkan dapat memberikan manfaat bagi mahasiswa. Video dibuat lebih menarik agar memacu minat belajar mahasiswa.

\section{Validasi Hasil Video Tutorial}

Validasi hasil video tutorial ini merupakan tahapan penilaian yang dilakukan oleh ahli. Penilaian meliputi dua bagian yaitu penilaian terhadap materi dan penilaian terhadap media. Ahli yang dilibatkan dalam penelitian ini adalah Organisasi Profesi yaitu DPD PORMIKI Jawa Tengah yang expert di bidang pengelolaan rekam medis dan informasi kesehatan untuk menilai dari segi materi dan ahli desain untuk menilai media.

Penilaian terhadap materi terdiri dari aspek penilaian isi materi dan strategi pembelajaran. Sedangkan penilaian terhadap media meliputi komunikasi, desain teknis, dan format tampilan. Item pertanyaan dalam penilaian materi sebanyak 10 pertanyaan dan pada penilaian media sebanyak 15 pertanyaan.(6)

Tabel 5.

Uji Validitas Video Tutorial

\begin{tabular}{clcccc}
\hline No & Video & Nilai & Uji Materi & \multicolumn{2}{c}{ Uji Media } \\
& & $80 \%$ & Sangat Valid & $79 \%$ & Kriteria \\
\hline 1 & Pendaftaran & $86 \%$ & Sangat Valid & $84 \%$ & Valid \\
2 & Koding & $72 \%$ & Valid & $85 \%$ & Sangat Valid \\
3 & Filing & & & Sangat Valid \\
\hline
\end{tabular}

Berdasarkan Tabel 5. diperoleh hasil bahwa uji materi pada video pendaftran mendapatkan nilai $80 \%$ dengan kriteria sangat valid. Pada uji media mendapatkan nilai $79 \%$ dengan kriteria valid. Uji materi pada video koding mendapatkan nilai 86\% dengan kriteria sangat valid. Uji media mendapatkan nilai $84 \%$ dengan kriteria sangat valid juga. Sedangkan uji materi pada video filing mendapatkan nilai $72 \%$ dengan kriteria valid dan uji media mendapatkan nilai 85\% dengan kriteria sangat valid.

Dari ketiga video tutorial diperoleh hasil valid dan sangat valid sehingga pembuatan video tutorial dapat dilanjutkan pada langkah uji coba. Penilaian uji validitas belum mencapai 100\% sehingga masih diperlukan upaya-upaya perbaikan dalam pembuatan video tersebut. Selain itu, dilakukan juga upaya FGD untuk mengetahui kekurangan video yang telah dihasilkan untuk dilakukan upaya perbaikan. Video yang telah diperbaiki, dilanjutkan ke tahap uji coba.

\section{Uji Coba Hasil Video Tutorial}

Desain produk yang telah dibuat tidak dapat langsung diuji coba dulu, tetapi harus dibuat terlebih dahulu, menghasilkan barang, dan barang tersebut diuji coba.(5) Pengujian dilakukan dengan tujuan untuk mendapatkan informasi apakah produk yang dihasilkan efektif dan efisien untuk diimplementasikan. Pengujian dapat dilakukan dengan eksperimen, yaitu membandingkan efektivitas dan efisiensi produk yang baru. Eksperimen dapat dilakukan dengan cara membandingkan dengan keadaan sebelum dan sesudah memakai produk yang dibuat atau dengan membandingkan dengan kelompok yang tetap menggunakan sistem lama.

Dalam penelitian ini menggunakan metode eksperimen One-Group Pretest-Posttest Design dimana desain ini terdapat pretest sebelum mendapat perlakuan yaitu melihat video tutorial. Dengan demikian hasil perlakuan dapat diketahui lebih akurat, karena dapat membandingkan dengan keadaan sebelum diberi perlakuan. Suatu produk dapat dikatakan efektif apabila nilai setelah lebih besar daripada nilai sebelum.(5) Video yang telah di uji validitas diuji cobakan kepada mahasiswa semester 1 Jurusan RMIK. Uji coba dilakukan kepada mahasiswa sebanyak 3 kelas dimana masing-masing akan diujicobakan terhadap video pendaftaran, koding, dan filing. Uji coba ini akan dinilai dengan 2 hal yaitu uji praktikalitas dan uji keefektivitasan. Uji praktikalitas bertujuan untuk mengetahui apakah video tutorial ini mudah 
untuk dimanfaatkan mahasiswa atau tidak dengan menyebarkan angket atau kuesioner uji praktikalitas. Uji keefektivitasan bertujuan untuk mengetahui apakah video pembelajaran efektif diterapkan kepada mahasiswa. Uji keefektivitasan dilakukan dengan memberikan pretest sebelum mahasiswa menonton video dan memberikan posttest setelah mahasiswa menonton video. Tahapan dalam uji ini adalah mahasiswa menjawab soal pretest terlebih dahulu. Setelah pretest, mahasiswa diberikan kesempatan untuk melihat video tutorial praktikum. Jika sudah selesai melihat video, mahasiswa mengerjakan soal posttest. Terakhir, mahasiswa mengisi kuesioner evaluasi atau uji praktikalitas yang ditampilkan dalam Tabel 6.

Tabel 6.

Rekapitulasi Pretest dan Posttest

\begin{tabular}{|c|c|c|c|c|c|c|}
\hline \multirow[t]{2}{*}{ No } & \multirow[t]{2}{*}{ Video } & \multirow[t]{2}{*}{$\sum$ Responden } & \multicolumn{2}{|c|}{ Pretest } & \multicolumn{2}{|c|}{ Posttest } \\
\hline & & & $\begin{array}{c}\text { Rata-Rata } \\
\text { Nilai }\end{array}$ & $\%$ Kelulusan & $\begin{array}{c}\text { Rata-Rata } \\
\text { Nilai }\end{array}$ & $\%$ Kelulusan \\
\hline 1 & Pendaftaran & 37 & 69 & $70 \%$ & 90 & $100 \%$ \\
\hline 2 & Koding & 35 & 85 & $91 \%$ & 96 & $100 \%$ \\
\hline 3 & Filing & 31 & 85 & $94 \%$ & 92 & $100 \%$ \\
\hline
\end{tabular}

Berdasarkan rekapitulasi pretest dan posttest video pendaftaran, pengumpulan data dilakukan kepada 37 responden dengan diperoleh hasil bahwa rata-rata pretest mahasiswa adalah 69 dan hasil posttest naik dengan rata-rata 90 . Persentase kelulusan pretest sebanyak 70\% dan setelah posttest naik menjadi 100\% lulus semua. Rekapitulasi pretest dan posttest video koding, pengumpulan data dilakukan kepada 35 responden dengan diperoleh hasil bahwa rata-rata pretest mahasiswa adalah 85 dan hasil posttest naik dengan rata-rata 96. Persentase kelulusan pretest sebanyak 91\% dan setelah posttest naik menjadi 100\% lulus semua. Sedangkan rekapitulasi pretest dan posttest video filing, pengumpulan data dilakukan kepada 31 responden dengan diperoleh hasil bahwa rata-rata pretest mahasiswa adalah 85 dan hasil posttest naik dengan rata-rata 92. Persentase kelulusan pretest sebanyak 94\% dan setelah posttest naik menjadi 100\% lulus semua.

Efektivitas media pembelajaran dapat dilihat berdasarkan nilai pretes dan posttest mahasiswa. Berdasarkan data yang diperoleh terhadap penilaian ketiga video tersebut, terjadi kenaikan rata-rata nilai dan persentase kelulusan pada pretest ke posttest. Hal ini dapat dikatakan bahwa terjadi peningkatan hasil belajar mahasiswa setelah mahasiswa melihat dan mempelajari suatu kompetensi melalui video pembelajaran. Hal ini serupa dengan hasil penelitian Andreas (2018) bahwa diperoleh hasil yang sama yaitu terjadi peningkatan hasil belajar mahasiswa setelah diberikan media pembelajaran berbasis video tutorial.(4)

Tabel 7.

Rekapitulasi Uji Praktikalitas

\begin{tabular}{clccc}
\hline No & Video & $\sum$ Responden & Rerata \% Uji & Kriteria \\
\hline 1 & Pendaftaran & 36 & $87 \%$ & Sangat Praktis \\
2 & Koding & 34 & $79 \%$ & Praktis \\
3 & Filing & 31 & $82 \%$ & Sangat Praktis \\
\hline
\end{tabular}

Berdasarkan uji praktikalitas pada video pendaftaran terhadap 36 responden (Tabel 7), diperoleh hasil rata-rata persentase nilai uji sebesar $87 \%$. Kriteria dalam uji tersebut diperoleh hasil bahwa video pendaftaran dinilai sangat praktis untuk digunakan oleh mahasiswa. Uji praktikalitas pada video koding terhadap 34 responden diperoleh hasil rata-rata persentase nilai uji sebesar 79\%. Kriteria dalam uji tersebut diperoleh hasil bahwa video koding dinilai praktis untuk digunakan oleh mahasiswa. Sedangkan uji praktikalitas pada video filing terhadap 31 responden diperoleh hasil rata-rata persentase nilai uji sebesar $82 \%$. Kriteria dalam uji tersebut diperoleh hasil bahwa video filing dinilai sangat praktis untuk digunakan oleh mahasiswa. Dari ketiga video yang dihasilkan diperoleh kesimpulan bahwa 2 video sangat praktis dan 1 vdeo praktis. Hal ini menunjukkan bahwa video yang telah dibuat dapat dimanfaatkan oleh mahasiswa dengan mudah. Hal serupa juga telah dilakukan dalam penelitian Ritonga (2020) bahwa video tutorial yang telah diujicobakan kepada mahasiswa diperoleh hasil praktikalitas sebesar 73,33\% yang juga 
termasuk dalam kategori praktis.(6)Selain itu, media pembelajaran berbasis video tutorial juga mampu meningkatkan minat pengguna dalam proses pembelajaran.(10)

\section{Kesimpulan}

Berdasarkan hasil uji validitas yang didapatkan pada penelitian maka dapat disimpulkan bahwa tiga video tutorial praktikum manajemen rekam medis yang dihasilkan meliputi video pendaftaran, video koding, dan video filing dapat dinyatakan valid. Kevalidan video dilihat dari validasi materi dan validasi media. Hasil uji efektivitas menunjukkan bahwa video tutorial praktikum efektif mampu meningkatkan kemampuan mahasiswa dalam melaksanakan praktikum manajemen rekam medis. Sedangkan hasil uji praktikalitas, ketiga video dinilai praktis dan sangat praktis oleh mahasiswa sehingga dapat disimpulkan bahwa video tersebut bermanfaat dan mudah digunakan oleh mahasiswa. Saran dalam penelitian ini adalah perlu dilakukan pengembangan video tutorial praktikum pada mata kuliah yang lain agar lebih banyak lagi perbendaharaan video tutorial bidang RMIK. Selain itu, perlu adanya peningkatan kualitas video tutorial praktikum agar mahasiswa semakin tertarik dan kompetensi mahasiswa tetap tercapai.

\section{Ucapan Terimakasih}

Terima kasih kami sampaikan kepada Direktur Poltekkes Kemenkes Semarang, melalui DIPA Poltekkes Kemenkes Semarang ini kami dapat memperoleh pendanaan penelitian ini. Terima kasih juga kami sampaikan kepada semua pihak yang terlibat dalam penelitian ini.

\section{Daftar Pustaka}

1. Polkesmar. Kurikulum Pendidikan Diploma 3 Rekam Medis dan Informasi Kesehatan. Semarang: Polkesmar; 2019.

2. $\quad$ Arsyad A. Media Pembelajaran. 1st ed. Jakarta: PT Raja Grafindo Persada; 2002.

3. Sugiarto; SIP. Strategi Pembelajaran Berbasis Gaya Belajar Mahasiswa Prodi D III Rekam Medis Informasi Kesehatan Politeknik Kesehatan Kemenkes Semarang. 2013; Available from: http:// repository.poltekkes-smg.ac.id//index.php?p=show_detail\&id=12547

4. Andreas LO, Gusmareta Y. Pengembangan Media Pembelajaran Mata Kuliah Mekanika Tanah Dan Teknik Pondasi Berbasis Video Tutorial Laras. J Chem Inf Model. 2019;53(9):1689-99.

5. Sugiyono. Metode Penelitian Pendidikan. Bandung: Alfabeta; 2016.

6. Anggi Merdiansyah Ritonga, Imam Syofii D. Pengembangan M E Dia Pembelajaran Video Tutorial Pada Praktikum Mata Kuliah Korosi Dan Teknik. J Pendidik Tek Mesin Vol. 2020;7(Mei).

7. Budi SC. Manajemen Unit Kerja Rekam Medis. Yogyakarta: Quantum Sinergis Media; 2011.

8. $\quad$ Sudra RI. Rekam Medis. Banten: Universitas Terbuka; 2020.

9. Depkes RI. Pedoman Penyelenggaraan dan Prosedur Rekam Medis di Rumah Sakit. Jakarta: Depkes RI; 1997.

10. Kartono G, Mesra M, Azis ACK. Pengembangan Media Ajar Grafis Komputer Materi Wpap Dalam Bentuk E-Book Dan Video Tutorial Bagi Mahasiswa Seni Rupa. Gorga J Seni Rupa. 2020;9(1):127. 